\title{
Assessment of Rheumatoid Arthritis in Clinical Care
}

\author{
Romatoid Artritin Klinik Değerlendirmesi
}

\author{
Tuulikki Sokka \\ Jyväskylä Central Hospital, Jyväskylä, Finland
}

\begin{abstract}
Quantitative clinical monitoring of patients with musculoskeletal conditions should be included in the infrastructure of every clinical practice. Quantitative monitoring improves the physician's capacity to assess and document a patient's clinical status and changes over time, which leads to greater accuracy in the underlying rationale for clinical decisions. Furthermore, routine data collection in consecutive patients facilitates analyses of groups of patients over long periods in usual care, beyond information that can be obtained from randomized clinical trials.

(Turk J Rheumatol 2010; 25: 1-11)

Key words: Rheumatoid arthritis, disease activity, clinical evaluation, outcomes
\end{abstract}

Received: 10.01 .2010

Accepted: 03.02 .2010

\section{Özet}

Kas-iskelet sistemi hastalığı olan bireylerin kantitatif izlemi her klinik uygulamanın parçası olmalıdır. Kantitatif izlem, hekimin hastanın klinik durumu ve zaman içindeki değișimini değerlendirme kapasitesini arttırır ve daha doğru klinik kararlar vermesini sağlar. Ayrıca ardısıı hastalarda rutin veri toplama, randomize klinik çalıșmalardan elde edilebilecek bilgiden ötede uzun süre boyunca hasta gruplarının analizini kolaylaștırır.

(Turk J Rheumatol 2010; 25: 1-11)

Anahtar sözcükler: Romatoit artrit, hastalık aktivitesi, klinik değerlendirme, sonuçlar

Alındığı Tarih: 10.01.2010

Kabul Tarihi: 03.02.2010

\section{Introduction}

Quantitative clinical monitoring of musculoskeletal conditions and inflammatory joint diseases is challenging compared to quantitative monitoring of conditions such as hypertension or hyperlipidemia, for which single "gold standard" measures can be used as an indicator of clinical status and changes over time in every individual patient. Several types of measures have been used traditionally to assess rheumatoid arthritis (RA), including joint assessment, laboratory tests, imaging, and patient self-report measures, often in an index of several types of measures. Each type of measure has limitations and provides only a reflection of the underlying inflammatory process. A single gold standard to define disease activity in RA does not exist and indices of multiple disease activity measures must be used.

Quantitative monitoring of RA as part of daily clinical practice has certainly improved since Dr Wright's observa- tion in 1983 that "clinicians may all too easily spend years writing 'doing well' in the notes of a patient who has become progressively crippled before their eyes ..." (1). Standard quantitative monitoring with a treatment goal has been shown to result in better patient outcomes in randomized clinical trials. Quantitative monitoring has also contributed to improved long-term outcomes for RA in usual clinical care.

One of the earliest proposals for an active monitoring and treatment strategy for RA was expressed by Luukkainen et al. in 1978 "...In our opinion gold treatment ought to be started in the early stages of RA, before the development of erosions. We are treating not only the actual inflammation of the joints but also the quality of the patient's life for many decades in the future" (2). Benefits of quantitative monitoring of RA are obvious and hurdles removed that prevent quantitative monitoring in every-day clinical care concerning disease activity and beyond.

Address for Correspondence: Tuulikki Sokka, MD, PhD, Arkisto/Tutkijat, Jyväskylä Central Hospital, 40620 Jyväskylä, Finland Phone: +358 407352087 Fax:+358 142691275 E-mail: tuulikki.sokka@ksshp.fi 
This article describes measures to assess clinical status of patients with RA and reviews some observations based on standard monitoring of patients with RA in daily clinical practice in a multinational collaborative database called Quantitative Standard Monitoring of Patients with RA (QUEST-RA).

\section{Measuring disease activity leads to lover disease activity levels}

Most clinical trials are designed to analyze differences between active and control treatments rather than to attain a certain clinical status, based on requirements for registration of new agents. In these registration trials, an extensive battery of disease activity and other measures are collected at study visits to document patient status. The measures are analyzed to determine whether statistically significant differences are seen between patients treated with a test therapy compared with a control therapy. The measures are not used to guide therapies. By contrast, a few trials involving available agents may be termed "strategy trials," as they involve adjustment of therapies according to a status of remission or low disease activity to achieve a predetermined treatment outcome.

The Finnish Combination Treatment Trial (FIN-RACo) was the first clinical trial with a remission as the primary outcome measure (3). Over the 2-year study, treatments had to be adjusted if remission was not met. At the end of the study, disease activity score (DAS28) -remission rates were $68 \%$ in the combination arm and $41 \%$ in the monotherapy arm and American College of Rheumatology (ACR) remission rates were $42 \%$ vs. $20 \%$ in the two groups and were among the highest that have ever been seen in clinical trials or clinical care (4). The TICORA aimed at low disease activity of DAS $<2.4$ in the strategy arm, with frequent clinical visits and escalation of treatments (5). At the end of the trial, $65 \%$ of patients were in remission in the strategy arm vs. only $16 \%$ in routine care arm. The BeSt study had a treatment goal of DAS $\leq 2.4 ; 38 \%$ $46 \%$ of patients in the four arms were in remission at the end of intervention (6). In the 2-year CAMERA trial, 50\% of patients were in DAS 28 remission in an intensively computer-assisted monitoring group vs. $37 \%$ in the conventional group (7). Similarly, in the CIMESTRA trial, 2-year radiographic and clinical results were better in the strategy group vs. control group (8). Fransen et al. (9) compared a strategy group designed with routine disease activity measurements and the aim of DAS $28 \leq 3.2$ to a usual care group with no routine measuring. Over 24 weeks, patients in the strategy group received more antirheumatic drugs and had better outcomes than patients in the usual care group.

These clinical trials indicate that the practice of quantitative monitoring of RA leads to better outcomes than routine care without quantitative monitoring. Furthermore, a treatment target and quantitative monitoring have been important clinicial settings which have reported favorable long-term outcomes of RA in recent years (10-12).

\section{Measures of activity and damage to assess} rheumatoid arthritis

Measures used to assess patient status in RA include laboratory tests, radiographs, formal joint assessments, physical measures of functional status, global measures, and patient self-report questionnaires. These measures may be classified as measures of disease activity, measures of damage to joints and other organs, measures which assess both activity and damage, and long term outcomes $(13,14)$.

Measures of disease activity, such as joint swelling, are consequences of a dysregulation, analogous to elevated glucose in diabetes and elevated blood pressure in hypertension. Elevation in activity measures may be reversible and not necessarily harmful to a patient. However, unchecked dysregulation commonly leads to long term damage to organs, such as joints, blood vessels, kidneys, or others, if no therapy is instituted to reverse persistent disease activity.

Measures of damage such as radiographic changes and joint deformity are irreversible medically, although partially correctable by surgery in some situations. Measures which assess both activity and damage, such as functional status, pain and global status include both reversible and irreversible phenomena. Long term outcomes, such as work disability, joint replacement surgery and premature mortality, reflect the concerns of patients who have chronic diseases more directly than measures of activity or damage.

\section{Measures to Assess RA Disease Activity}

\section{Physician measures: joint assessment}

A careful joint examination is required to establish a diagnosis of RA (15), and quantitative counts of swollen and tender joints are the most specific measures for patient assessment (16-19). The number of swollen and tender joints is regarded as the most important measure for RA clinical trials to distinguish active from control treatments (20), and the best measure of status in usual clinical care (21). The joint count is included in a Core Data Set (22-24) and in disease activity indices that will be discussed later.

A 28 joint count includes 10 proximal interphalangeal (PIP) and 10 metacarpal phalangeal (MCP) joints of the hands, 2 wrists, 2 elbows, 2 shoulders and 2 knees (25). Recent studies have used a 42 joint count, which includes the 28 joint count and 10 metatarsal phalangeal (MTP) joints of the feet, hips and ankles (26). Joints are assessed according to a standard protocol for evaluation of rheumatoid arthritis (SPERA) (27) not only for swelling and tenderness, as in clinical trials, but also for limited motion or deformity, which must be included to assess long-term outcomes. 


\section{Laboratory tests}

The majority of patients with RA have an elevated erythrocyte sedimentation rate (ESR) and C-reactive protein (CRP) (28). An abnormal ESR or CRP often provide inclusion criteria for clinical trials (29). An ESR less than 30 $\mathrm{mm} / \mathrm{h}$ in a woman and less than $20 \mathrm{~mm} / \mathrm{h}$ in a man is required to meet $A C R$ remission criteria (30).

Reductions in ESR and CRP are seen in groups of patients in all successful clinical trials of RA therapies which indicate efficacy of an active treatment compared to a control treatment. However, no blood test is abnormal in more than $75 \%$ of patients with rheumatoid arthritis, or normal in more than $99 \%$ of normal individuals. Indeed, more than $40 \%$ of RA patients have normal values for the acute phase reactants, $\operatorname{ESR}$ and $\operatorname{CRP}(28,31)$.

The majority of patients with RA also have positive tests for rheumatoid factor (RF) and antibodies to cyclic citrullinated peptides (anti-CCP) (32-35). RF is included in classification criteria for RA (36) and anti-CCP is being considered for revised criteria. However, an extensive meta-analysis indicated that anti-CCP was normal in 33\% and RF in $31 \%$ of patients with RA (35). RF or anti-CCP cannot be used as disease activity measures and their predictive value of outcomes is limited (37).

\section{Patient questionnaires}

In RA, inflammation of joints and other systems affects patient functional status, causes pain, fatigue, and other symptoms, which resolve as inflammation responds to treatments. Patient self-report has become prominent in rheumatology assessment, as patient is the most accurate source for quantitative information concerning functional capacity, pain, global health, fatigue, psychological distress etc.

The self-report health assessment questionnaire (HAQ) (38) provided a milestone in rheumatology, with a scale of 20 activities of daily living ( $A D L$ ) in 8 categories to assess functional disability, with 4 patient response options: "without any difficulty" =0, "with some difficulty" =1, "with much difficulty" $=2$ and "unable to do" $=3$. The 8 categories of 2 or 3 ADL address dressing, arising, eating, walking, bathing, reaching, gripping, and performing errands. The score for each category is the highest score among the 2 or 3 ADL within the category; 1 is added to the score if the patient uses aids or devices for that category, so the final score is $\mathbf{0 - 3}$. The total score is the mean score derived from 8 scores, one for each category.

Several modifications of the HAQ have been developed to provide simplified scoring in routine clinical care and allow the clinician to visualize an ADL score. The most widely used modifications are the modified HAQ (MHAQ) which includes only one question in each of the 8 HAQ categories (39). A further modification is the multidimensional HAQ (MDHAQ), which includes $10 \mathrm{ADL}, 8$ from the MHAQ and two complex activities, 3 psycho- logical items (40-42), as well as $10 \mathrm{~cm}$ visual analog scales for pain, global health, and fatigue.

Patient questionnaires concerning functional status provide the most significant prognostic clinical measure for all important long-term outcomes of RA, other than radiographic scores for which radiographs are most significant in prognosis. Physical function scores are the most significant prognostic measures for functional status $(43,44)$ work disability $(45-47)$ costs $(48)$ joint replacement surgery (49) and premature death $(43,50-56)$ at higher levels than radiographic scores or laboratory tests. Patient questionnaire data concerning physical function predict RA mortality at levels comparable to blood pressure, cholesterol, and smoking, as risk factors for premature cardiovascular death (52). In fact, physical fitness and performance are universal predictors for survival in diseased and non-diseases populations (57) and can be assessed quantitatively according to a variety measures ranging from simple patient self-report questionnaires to full scale performance tests, among which patient selfreport is the most cost-effective and accurate.

In addition to Core Data Set items, a clinical questionnaire may include a Rheumatoid Arthritis Disease Activity Index (RADAI) self-report joint count (58), duration of morning stiffness, years of education, height and weight for body mass index, life-style choices such as smoking and the frequency of physical exercise, and work status. These measures are included on the MDHAQ, and a questionnaire used in the QUEST-RA program,(59) which will be described below.

Questionnaires that can be used in routine clinical care are easily completed by patients and easily scored by health professionals. Some questionnaires that are designed for clinical research such as the SF-36 (60) which is a "generic," non-disease specific" questionnaire and can be used to compare the impact of rheumatoid arthritis on daily life with the impact of, say, congestive heart failure or lymphoma. These questionnaires have complex scoring, and were designed for clinical research rather than routine clinical care.

\section{Indices to measure RA disease activity}

Indices of 3-7 measures used in clinical assessment of RA disease activity are based on a Core Data Set of 7 measures including 3 from a health professional (swollen joint count, tender joint count, global estimate of status), 1 from a laboratory (ESR or CRP), and 3 from a patient (physical function, pain, patient global estimate of status). The earliest use of an index was defined by the American College of Rheumatology (ACR) as a 20\%, 50\%, or $70 \%$ improvement in swollen and tender joint count plus 3 of the other 5 measures, known as ACR20, ACR50 and ACR70 responses $(23,61)$. The ACR criteria measure change compared to baseline, rather than absolute status. Therefore, a $50 \%$ improvement can be achieved 
when tender and swollen joint counts are decreased from 20 to 10 or 4 to 2 (provided that $3 / 5$ other ACR core data set measures also are improved $50 \%$ ).

Inflammatory activity can be assessed according to absolute indices of efficacy or disease "state," which may be defined as a measurable, cross-sectional level of disease activity. The most widely-used index, the disease activity score (DAS, DAS 28) (62-64) includes swollen joint count, tender joint count, ESR or CRP, and patient global estimate, calculated using a computer website or a DAS calculator. A simplified disease activity index (SDAI) (65) includes five measures - the four DAS28 measures plus a physician assessment of global status. The clinical disease activity index (CDAI) (66) deletes the CRP from the SDAI. Other RA indices have been developed: the mean overall index for rheumatoid arthritis (MOI-RA) (67) which includes all 7 Core Data Set measures; and the LUNDEX (68), an index designed to incorporate patients' adherence to therapy.

Indices have also been designed based on PRO measures only such as a routine assessment of patient index data 3 (RAPID3) $(69,70)$. An index of physical function, pain, and patient global status distinguishes active from control treatment in clinical trials involving traditional $(71,72)$ and biologic therapies at levels similar to the DAS 28 and CDAI (73).

\section{"Disconnect" of inflammatory activity, damage, and outcomes}

Disease activity measures are sensitive to change over a period of weeks to months and are regarded as shortterm surrogate markers for long-term joint damage, such as joint deformity and radiographic progression, and clinical outcomes, such as work disability, joint replacement surgery, and premature mortality (52), which develop over years to decades.

However, it was recognized already during the mid 1980s that short term drug efficacy was not necessarily translated into long-term effectiveness (43). Several studies have indicated progression of radiographic damage and decline of physical function over 5-10 years while measures of inflammatory activity were stable or improved [reviewed in (74)].

One example is the FIN-RACo trial which documented that suppression of inflammation at a level of $20 \%$ or $50 \%$, i.e., ACR20 or ACR50 does not provide optimal improvement in outcomes. Among patients whose inflammation was controlled to a status of remission at 6 months, no patient was receiving work disability payments $4 \frac{1}{2}$ years later. By contrast, $22 \%$ of patients who had ACR20 or ACR50 responses, and 54\% of patients who did not have ACR20 responses, were receiving work disability payments at 5 years after baseline (75). Therefore, improvements greater than $50 \%$ in RA disease activity measures appear needed to prevent adverse long-term outcomes in many patients.

\section{Assessment of joint damage of RA \\ Radiographs}

The two most widely used quantitative measures of radiographs are based on scores developed by Sharp (76-78) and Larsen $(79,80)$. The Sharp method involves separate scores for erosions and joint space narrowing, scored on 0-5 scales. The Sharp score modified by van der Heijde is widely used in clinical trails; total scores range from 0 to 448 units (81-83).

The Larsen method is based on a global score for each joint (84). Kaarela and Kautiainen (85) suggested a range of score of 1-100 including 10 MCP joints, wrists, and the $2^{\text {nd }}$ to the $5^{\text {th }}$ MTP joints. Rau and Herborn (86) introduced a modified Larsen score which counts the percentage of the loss of joint surface, and is more recently known as a Ratingen score (87). Scores based on the Sharp and Larsen approaches are correlated significantly (88).

\section{Quantitative measuring beyond disease activity}

As suggested above, disease activity is only one dimension of manifestations of RA and may not be sufficient to provide an comprehensive picture of patient status over time. A standard format for efficient collection of data in patients with RA has been developed in clinical research over the last two decades, termed a "standard protocol to evaluate rheumatoid arthritis" (SPERA) $(27,89)$. This format has proven useful to collect data in a number of studies concerning prognosis and monitoring of patients, including development of a 28 joint count (25); observation of radiographic damage in most patients within the first two years of disease (90); recognition that patient questionnaires are correlated significantly with joint counts, radiographic scores and laboratory tests (91) while providing more significant predictors of work disability $(45)$ and mortality $(52,54)$ than traditional measures; and observations that a relatively small proportion of patients was eligible for clinical trials in contemporary care of RA $(26,29)$. The SPERA format was used to document that patients with RA in 2000 had considerably better status than all patients seen in 1985 in the same clinical setting (41). SPERA has been used to collect comprehensive baseline clinical data in more than 8,000 patients in 32 countries for the QUESTRA program (59, 92-95).

SPERA includes data from both the patient and clinician. The patient completes a standard self-report questionnaire-a HAQ (38), MDHAQ (69, 70), QUEST-RA comprehensive $\mathrm{HAQ}$, or variant for physical function, questions concerning pain, global status, fatigue, self-report joint count, duration of morning stiffness, years of education, height and weight for body mass index, life-style choices such as smoking and physical exercise, and work status. 
The clinician completes a SPERA which addresses:

a) review of clinical features, including classification criteria, extra-articular features, comorbidities, and relevant surgeries;

b) all previous and present DMARDs, their adverse events, and reasons for discontinuation;

c) a 42-joint count (96) which includes swollen and tender joints, as well as joints with limited motion or deformity.

The first two SPERA documents are designated as a permanent document that can be updated if needed. SPERA captures most important baseline information that a clinician should know to care for a patient with RA, as well as baseline information for a clinical trial or observational research study. It incorporates the 5 core domains listed in a consensus for long-term observational studies from an Outcome Measures in Rheumatoid Arthritis Clinical Trials (OMERACT) conference in 1998: health status, disease process, damage, mortality, and toxicity/ adverse reactions (97). A database derived from SPERA or similar protocols could be used at baseline for all clinical trials as well as in standard care to facilitate analyses of long-term outcomes of rheumatic diseases beyond disease activity measures.

The QUEST-RA international database to characterize disease activity and outcomes in patients seen in usual care of RA

QUEST-RA is a unique multinational collaboration to review patients with RA for their clinical status and is therefore described here as an successful example of quantitative clinical measuring of RA as part of routine clinical care. QUEST-RA collects data from consecutive, unselected, patients with RA with no other selection criteria but adult-onset RA. Three or more clinics are invited in each country, to ensure generalizability of the data. In each clinic, 100 or more patients are assessed according to the SPERA evaluation described above. The primary aim of the QUEST-RA program is to provide "hands-on" experience to rheumatologists with patient questionnaires and standard clinical monitoring as part of usual care, in order to advance inclusion of quantitative data at every rheumatology visit.

QUEST-RA was initiated in January 2005. By June 2009, the program enrolled 8,039 patients from 86 sites in 32 countries including Argentina, Brazil, Canada, Denmark, Egypt, Estonia, Finland, France, Germany, Greece, Hungary, India, Ireland, Italy, Japan, Kenya, Kosovo, Latvia, Lithuania, Morocco, the Netherlands, Norway, Poland, Romania, Russia, Serbia, Spain, Sweden, Turkey, United Arab Emirates, United Kingdom, and the United States (98).

QUEST-RA provides data on current clinical status, disease activity, and patient reported health in many countries (59, 92-95, 98-100) and serves as an example of the value of data collection in individual clinics. Some observations from QUEST-RA will be reviewed here.

\section{A strong association of disease activity and Gross Domestic Product (GDP)}

The mean disease activity on DAS28 ranged between 3.1 and 6.0 among the 25 countries which were evaluated by April 2008 (93). Disease activity levels differed substantially between countries with higher GDP>24K USD and lower GDP<11K USD at much greater levels than according to whether patients were currently taking or not taking methotrexate, prednisone, and/or biologic agents. Disease activity was associated significantly with GDP [r=-0.78 (95\% Cl-0.56 to -0.90$), r^{2}=61 \%$ ] (Figure 2).

Among 48 clinical settings which participated by April 2007, low disease activity of DAS28 <3.2 was seen in more than $50 \%$ of patients at 8 sites in 6 countries: the Netherlands, Finland, USA, Greece, Denmark, and Spain

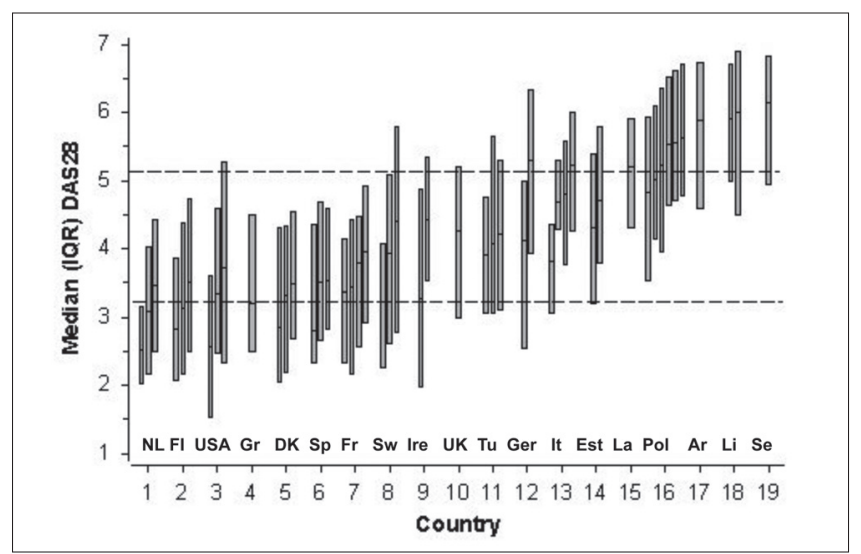

Figure 1. Disease activity in the QUEST-RA study

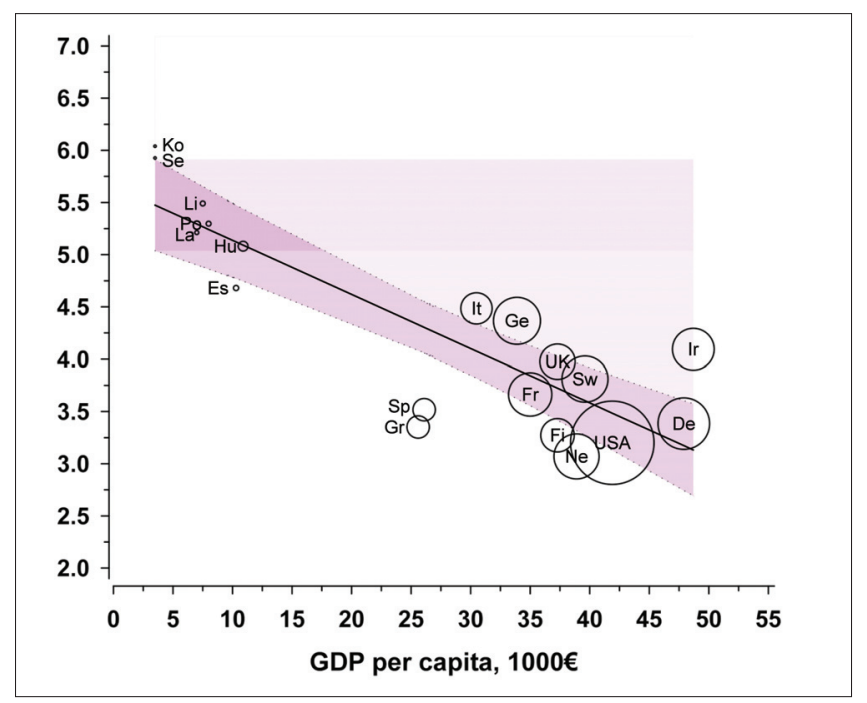

Figure 2. Association between gross domestic product (GDP) and disease activity (DAS28) in 19 countries in the QUEST-RA study 
(Figure 1) (59). The data extend observations that most patients at some clinical sites would not be eligible for most RA clinical trials due to low disease activity $(26,101)$. By contrast, more than $50 \%$ of patients had DAS $28>5.1$, indicating high disease activity in 5 countries, including Latvia, Poland, Argentina, Lithuania and Serbia, all low GDP countries.

These findings are consistent with extensive evidence that macro-economic variables provide significant explanation of variation in health outcomes among different nations. GDP predicts variation in overall mortality, infant mortality, and life expectancy (102-104) in different countries, as well as outcomes of specific diseases, such as 5-year survival of cancer in 22 European countries (105).

\section{Is it better to be a woman or a man with RA-does gender affect RA disease activity measures?}

The issue of possible effects of gender on disease activity at levels close to remission has emerged at this time, when patient clinical status is improved compared to earlier decades, due to better treatment strategies and biologic agents (106). Remissions are seen more frequently than earlier decades, although influenced by definition used $(98,107)$. Some studies suggest that male gender is a major predictor of remission in early RA $(108,109)$ and some others that men have better responses to treatments with biologic agents than women (110-112). All biologics clinical trials use DAS 28 for the definition of remission (107).

These discussions led to studies of the influence of gender on DAS28 remission. Among $>6.000$ patients, women had higher scores than men for all ACR core data set measures. Overall, $30 \%$ of men and $17 \%$ of women were in DAS 28 remission $(92,98)$. Differences in remission rates were most pronounced in patients who had no swollen joints: many fewer women than men (42\% vs. $58 \%$ ) met DAS 28 remission. These observations indicate that lower remission rates in females are accounted for other components of the indices (than the number of swollen joints) such as number of tender joints, patient self-report scores, and higher normal ESR in women (113). Higher DAS 28 remission rates in men might reflect at least in part gender differences in indices rather than true gender differences in RA disease activity!

\section{Variation in therapies for RA}

Clinical trials provide evidence of efficacy of new therapies. Register data are available in a few countries concerning clinical safety of biological treatments. Cohort studies that describe DMARDs for RA represent a small, selected minority of all patients. These sources cannot provide an overall picture of the drug treatment for RA and therefore, we sought to analyze the QUEST-RA database for RA therapies.

In the QUEST-RA patients, the use of intra-muscular gold as the first DMARD dropped from $>60 \%$ in patients who were diagnosed with RA the 1970's to $<2 \%$ in patients who were diagnosed with RA in the 2000's, and the use of MTX ascended from $2 \%$ to $>50 \%$ as the initial DMARD.

At 61 QUEST-RA sites in 21 countries, $63 \%$ of patients were taking methotrexate and $20 \%$ were taking biologic agents in 2005-07 (114). Fewer than 20\% of patients were currently taking oral glucocorticoids in Denmark and the Netherlands, in contrast to $83 \%$ of patients in Lithuania. More than $25 \%$ of patients were taking biologic agents in the USA, France, Sweden, Ireland, and Latvia, although the high percentage in some countries may be explained by prior inclusion of some patients in randomized clinical trials of biologic agents. Fewer than $10 \%$ of patients were taking biologic agents in Serbia, Estonia, Argentina, Turkey, Poland, and Lithuania.

Methotrexate was taken at some time by $86 \%$ of all patients, prednisone $72 \%$, sulfasalazine $46 \%$, antimalarials $42 \%$, any biologic agent by $24 \%$, intra muscular gold by $23 \%$, and leflunomide by $22 \%$ of all patients. Cyclosporine-A, azathioprine, and D-penicillamine were taken by $7-10 \%$ of patients (114).

In addition, longer use of many DMARDs was associated with a reduced risk of cardiovascular events (95).

\section{Physical activity in RA population-a moving target?}

Regular physical activity is associated with decreased morbidity and mortality at a population level (115). Traditionally, patients with RA were advised to avoid or limit physical exercises with a fear that physical exercises might increase disease activity and harm joints. Physical therapy for RA was directed to relieve pain, and included heat and cold therapy, splints, range of motion exercises, and other conservative regimens. Indeed, decades ago many RA patients had severe destructive disease and instructions to participate in rigorous physical activities, and even minimal exercise were regarded as inappropriate.

Over the past decade, the importance of exercise as a component of the management of RA has been recognized with recommendations of regular physical exercises (116), benefits such as increased muscle force and aerobic capacity, decreased inflammation and pain, improved function, and sense of well-being (117-119) have been observed in patients with RA. Therefore, it was our interest to study whether individuals with RA participate in exercises in different countries.

Data from 21 countries were analyzed (99). Only 13.8\% of all patients reported physical exercise $\geq 3$ times weekly. The majority of the patients were physically inactive with no regular weekly exercises: $>80 \%$ in seven countries, $60-80 \%$ in 12 countries, and $45 \%$ and $29 \%$ in two other countries. Physical inactivity was associated with female sex, older age, lower education, obesity, comorbidity, low functional capacity, and higher levels of disease activity, pain, and fatigue. These data may alert rheumatologists to motivate their patients to increase physical activity levels. 


\section{Work disability as an outcome measure}

Work disability is a major consequence of RA $(43,120-122)$. Although cumulative over time, $20-30 \%$ of patients become permanently work-disabled in the first 2-3 years of the disease (123). Rapid remission in early disease appears a beneficial strategy against work disability in RA (75).

Availability of biologic agents over the past decade has led to expectations of reduced work disability rates in RA (124), according to observations in clinical trials (125-129). However, reports of clinical cohorts indicate that work disability remains a major problem in RA (130-133). Possible explanations include that the timing of biologic agents after joint damage is seen may be too late in many cases at this time, and/or that use of biologic agents is unusual in many countries for financial reasons (114).

As noted above, work disability is identified most significantly by measures of functional status. The risk of work disability in RA is associated not only with traditional articular, radiographic and laboratory measures of disease activity and severity, but as much or more with demographic, socioeconomic, vocational, functional and social policy variables $(120,134)$. Although work disability is one of the most important outcomes in RA, cultural and economical differences between societies (135) may compromise its value as an outcome measure.

Most studies concerning work disability in RA have been conducted in North America and Western Europe, and little is known about employability of RA patients in other countries. QUEST-RA provided an opportunity to study issues related to work disability in a multinational setting (136).

At the time of first symptoms, $86 \%$ of men (range $57 \%-100 \%$ among countries) and $64 \%$ (19\%-87\%) of women $<65$ years were working. More than one-third $(37 \%)$ of these patients reported subsequent work disability because of RA. Among 1,756 patients whose symptoms had began during the 2000 's, the probability of continuing to work was $80 \%(95 \% \mathrm{Cl} 78 \%-82 \%)$ at 2 years and $68 \%$ (95\% Cl 65\%-71\%) at 5 years, with similar patterns in highGDP and low-GDP countries. Patients who continued working vs. stopped working had significantly better clinical status for all clinical status measures and patient selfreport scores, with similar patterns in high-GDP and lowGDP countries. However, patients who had stopped working in high-GDP countries had better clinical status than patients who continued working in low-GDP countries. The most significant identifier of work disability in all subgroups was HAQ functional disability score.

QUEST-RA data indicate that work disability rates remain high among people with RA during this millennium. The data showed that in low-GDP countries, people remain working with high levels of disability and disease activity. Indeed, disease activity and disability levels were as high in working people in low-GDP countries as in workdisabled people in high-GDP countries. The data indicate that cultural and economic differences between societies affect work disability as an outcome measure for RA.

\section{Conclusions}

Quantitative assessment of rheumatoid arthritis in standard clinical care is valuable to improve the quality of visits for patients and health professionals.. In addition, the data provide opportunities for comparison of groups of patients to improve knowledge of disease in real life settings. This review indicates that it is possible for any rheumatologist to turn clinical work to clinical science by collecting quantitative measures in routine care settings. Data from an international collaboration are presented to illustrate the value of this activity.

\section{Conflict of Interest}

No conflict of interest is declared by the authors.

\section{References}

1. Smith T. Questions on clinical trials (editorial). $\mathrm{Br}$ Med J 1983; 287: 569.

2. Luukkainen $\mathrm{R}$, Kajander $\mathrm{A}$, Isomäki $\mathrm{H}$. Treatment of rheumatoid arthritis (letter). Br Med J 1978; 2: 1501.

3. Möttönen T, Hannonen P, Leirisalo-Repo $M$, Nissilä $M$, Kautiainen $\mathrm{H}$, Korpela $\mathrm{M}$ et al. Comparison of combination therapy with single-drug therapy in early rheumatoid arthritis: A randomised trial. FIN-RACo trial group. Lancet 1999; 353: 1568-73.

4. Makinen $H$, Kautiainen $H$, Hannonen $P$, Mottonen $T$, Leirisalo-Repo $M$, Laasonen $L$ et al. Sustained remission and reduced radiographic progression with combination disease modifying antirheumatic drugs in early rheumatoid arthritis. J Rheumatol 2007; 34: 316-21.

5. Grigor C, Capell H, Stirling A, McMahon AD, Lock P, Vallance $R$ et al. Effect of a treatment strategy of tight control for rheumatoid arthritis (the TICORA study): a single-blind randomised controlled trial. Lancet 2004; 364: 263-9.

6. Goekoop-Ruiterman YPM, de Vries-Bouwstra JK, Allaart CF, van Zeben D, Kerstens PJSM, Hazes JMW et al. Clinical and radiographic outcomes of four different treatment strategies in patients with early rheumatoid arthritis (the BeSt study): a randomized, controlled trial. Arthritis Rheum 2005; 52: 3381-90.

7. Verstappen SMM, Jacobs JWG, van der Veen MJ, Heurkens AHM, Schenk Y, Ter Borg EJ et al. Intensive treatment with methotrexate in early rheumatoid arthritis: aiming for remission. Computer Assisted Management in Early Rheumatoid Arthritis (CAMERA, an open-label strategy trial). Ann Rheum Dis 2007; 66: 1443-9.

8. Hetland ML, Stengaard-Pedersen $\mathrm{K}$, Junker $\mathrm{P}$, Lottenburger $\mathrm{T}$, Hansen I, Andersen LS et al. Aggressive combination therapy with intra-articular glucocorticoid injections and conventional disease-modifying anti-rheumatic drugs in early rheumatoid arthritis: second-year clinical and radiographic results from the CIMESTRA study. Ann Rheum Dis 2008; 67: 815-22. 
9. Fransen J, Moens HB, Speyer I, van Riel PLCM. Effectiveness of systematic monitoring of rheumatoid arthritis disease activity in daily practice: a multicentre, cluster randomised contolled trial. Ann Rheum Dis 2005; 64: 1294-8.

10. Sokka T, Kautiainen $H$, Häkkinen $K$, Hannonen P. Radiographic progression is getting milder in patients with early rheumatoid arthritis. Results of 3 cohorts over 5 years. J Rheumatol 2004; 31: 1073-82.

11. Pincus $\mathrm{T}$, Sokka $\mathrm{T}, \mathrm{K}$ Kautiainen $\mathrm{H}$. Patients seen for standard rheumatoid arthritis care have significantly better articular, radiographic, laboratory, and functional status in 2000 than in 1985. Arthritis Rheum 2005; 52: 1009-19.

12. Uhlig $T$, Heiberg $T$, Mowinckel $P$, Kvien TK. Rheumatoid arthritis is milder in the new millennium: health status in patients with rheumatoid arthritis 1994-2004. Ann Rheum Dis 2008; 67: 1710-5.

13. Pincus T, Callahan LF. Prognostic markers of activity and damage in rheumatoid arthritis: Why clinical trials and inception cohort studies indicate more favorable outcomes than studies of patients with established disease. $\mathrm{Br} J$ Rheumatol 1995; 34: 196-9.

14. Pincus T, Sokka T. Quantitative measures for assessing rheumatoid arthritis in clinical trials and clinical care. Best Pract Res Clin Rheumatol 2003; 17: 753-81.

15. Pincus T. The DAS is the most specific measure, but a patient questionnaire is the most informative measure to assess rheumatoid arthritis. J Rheumatol 2006; 33: 834-7.

16. Cooperating Clinics Committee of the American Rheumatism Association. A seven-day variability study of 499 patients with peripheral rheumatoid arthritis. Arthritis Rheum 1965; 8: 302-35.

17. Ritchie DM, Boyle JA, McInnes JM, Jasani MK, Dalakos TG, Grieveson $\mathrm{P}$ et al. Clinical studies with an articular index for the assessment of joint tenderness in patients with rheumatoid arthritis. Q J Med 1968; New Series 37: 393-406.

18. American Rheumatism Association. Dictionary of the rheumatic diseases vol. I: signs and symptoms. New York: Contact Associates International; 1982.

19. Decker JL. American Rheumatism Association nomenclature and classification of arthritis and rheumatism. Arthritis Rheum 1983; 26: 1029-32.

20. Bombardier C, Tugwell P, Sinclair A, Dok C, Anderson G, Buchanan WW. Preference for endpoint measures in clinical trials: results of structured workshops. J Rheumatol 1982; 9: 798-801.

21. Wolfe F, Pincus T, Thompson AK, Doyle J. The assessment of rheumatoid arthritis and the acceptability of self-report questionnaires in clinical practice. Arthritis Care Res 2003; 49: $59-63$.

22. Boers $M$, Tugwell P, Felson DT, van Riel PLCM, Kirwan JR, Edmonds JP et al. World Health Organization and International League of Associations for Rheumatology core endpoints for symptom modifying antirheumatic drugs in rheumatoid arthritis clinical trials. J Rheumatol 1994; 21(Suppl 41): 86-9.

23. Felson DT, Anderson JJ, Boers M, Bombardier C, Chernoff $M$, Fried B et al. The American College of Rheumatology preliminary core set of disease activity measures for rheumatoid arthritis clinical trials. Arthritis Rheum 1993; 36 : 729-40.

24. American College of Rheumatology Committee to Reevaluate Improvement Criteria. A proposed revision to the ACR20: The hybrid measure of American College of Rheumatology response. Arthritis Rheum 2007; 57: 193-202.

25. Fuchs HA, Brooks RH, Callahan LF, Pincus T. A simplified twenty-eight joint quantitative articular index in rheumatoid arthritis. Arthritis Rheum 1989; 32: 531-7.
26. Sokka T, Pincus T. Eligibility of patients in routine care for major clinical trials of anti-tumor necrosis factor alpha agents in rheumatoid arthritis. Arthritis Rheum 2003; 48: 313-8.

27. Pincus $\mathrm{T}$, Brooks $\mathrm{RH}$, Callahan LF. A proposed standard protocol to evaluate rheumatoid arthritis (SPERA) that includes measures of inflammatory activity, joint damage, and longterm outcomes. JRheumatol 1999; 26: 473-80.

28. Sokka T, Pincus T. Erythrocyte sedimentation rate, C-reactive protein, or rheumatoid factor are normal at presentation in $35 \%-45 \%$ of patients with rheumatoid arthritis seen between 1980 and 2004: analyses from Finland and the United States. J Rheumatol 2009; 36: 1387-90.

29. Sokka T, Pincus T. Most patients receiving routine care for rheumatoid arthritis in 2001 did not meet inclusion criteria for most recent clinical trials or American College of Rheumatology criteria for remission. J Rheumatol 2003; 30: 1138-46.

30. Pinals RS, Masi AT, Larsen RA, et al. Preliminary criteria for clinical remission in rheumatoid arthritis. Arthritis Rheum 1981; 24: 1308-15.

31. Wolfe F, Michaud K. The clinical and research significance of the erythrocyte sedimentation rate. J Rheumatol 1994; 21 : 1227-37.

32. Schellekens GA, de Jong BAW, van den Hoogen FHJ, van de Putte LBA, van Venrooij WJ. Citrulline is an essential constituent of antigenic determinants recognized by rheumatoid arthritis-specific autoantibodies. J Clin Invest 1998; 101: 273-81.

33. van Gaalen FA, Linn-Rasker SP, van Venrooij WJ, de Jong BA, Breedveld FC, Verweij CL et al. Autoantibodies to cyclic citrullinated peptides predict progression to rheumatoid arthritis in patients with undifferentiated arthritis: a prospective cohort study. Arthritis Rheum 2004; 50: 709-15.

34. Riedemann JP, Muñoz S, Kavanaugh A. The use of second generation anti-CCP antibody (anti-CCP2) testing in rheumatoid arthritis-a systematic review. Clin Exp Rheumatol 2005; 23: S69-S76.

35. Nishimura K, Sugiyama D, Kogata Y, Tsuji G, Nakazawa T, Kawano $S$ et al. Meta-analysis: Diagnostic accuracy of anticyclic citrullinated peptide antibody and rheumatoid factor for rheumatoid arthritis. Ann Intern Med 2007; 146: 797-808.

36. Arnett FC, Edworthy SM, Bloch DA, McShane DJ, Fries JF Cooper NS et al. The American Rheumatism Association 1987 revised criteria for the classification of rheumatoid arthritis. Arthritis Rheum 1988; 31: 315-24.

37. Ursum J, Bos WH, van DN, Dijkmans BA, van SD. Levels of anti-citrullinated protein antibodies and IgM rheumatoid factor are not associated with outcome in early arthritis patients: a cohort study. Arthritis Res Ther 2010; 12: R8.

38. Fries JF, Spitz P, Kraines RG, Holman HR. Measurement of patient outcome in arthritis. Arthritis Rheum 1980; 23: 137-45.

39. Pincus T, Summey JA, Soraci SA, Jr., Wallston KA, Hummon NP. Assessment of patient satisfaction in activities of daily living using a modified Stanford health assessment questionnaire. Arthritis Rheum 1983; 26: 1346-53.

40. Pincus T, Swearingen C, Wolfe F. Toward a multidimensional health assessment questionnaire (MDHAQ): Assessment of advanced activities of daily living and psychological status in the patient friendly health assessment questionnaire format. Arthritis Rheum 1999; 42: 2220-30.

41. Pincus $T$, Sokka $T$, Kautiainen $H$. Further development of a physical function scale on a multidimensional health assessment questionnaire for standard care of patients with rheumatic diseases. J Rheumatol 2005; 32: 1432-9. 
42. Pincus $T$, Yazici $Y$, Bergman $M$. Development of a multidimensional health assessment questionnaire (MDHAQ) for the infrastructure of standard clinical care. Clin Exp Rheumatol 2005; 23: S19-S28.

43. Pincus $T$, Callahan LF, Sale WG, Brooks AL, Payne LE, Vaughn WK. Severe functional declines, work disability, and increased mortality in seventy-five rheumatoid arthritis patients studied over nine years. Arthritis Rheum 1984; 27: 864-72.

44. Wolfe F, Cathey MA. The assessment and prediction of functional disability in rheumatoid arthritis. J Rheumatol 1991; 18: 1298-306.

45. Callahan LF, Bloch DA, Pincus T. Identification of work disability in rheumatoid arthritis: Physical, radiographic and laboratory variables do not add explanatory power to demographic and functional variables. J Clin Epidemiol 1992; 45: 127-38.

46. Wolfe F, Hawley DJ. The longterm outcomes of rheumatoid arthritis: Work disability: A prospective 18 year study of 823 patients. J Rheumatol 1998; 25: 2108-17.

47. Sokka T, Kautiainen H, Möttönen T, Hannonen P. Work disability in rheumatoid arthritis 10 years after the diagnosis. J Rheumatol 1999; 26: 1681-5.

48. Lubeck DP, Spitz PW, Fries JF, Wolfe F, Mitchell DM, Roth SH. A multicenter study of annual health service utilization and costs in rheumatoid arthritis. Arthritis Rheum 1986; 29: 488-93.

49. Wolfe F, Zwillich SH. The long-term outcomes of rheumatoid arthritis: A 23-year prospective, longitudinal study of total joint replacement and its predictors in 1,600 patients with rheumatoid arthritis. Arthritis Rheum 1998; 41: 1072-82.

50. Wolfe F, Kleinheksel SM, Cathey MA, Hawley DJ, Spitz PW, Fries JF. The clinical value of the Stanford health assessment questionnaire functional disability Index in patients with rheumatoid arthritis. J Rheumatol 1988; 15: 1480-8.

51. Leigh JP, Fries JF. Mortality predictors among 263 patients with rheumatoid arthritis. J Rheumatol 1991; 18: 1307-12.

52. Pincus T, Brooks RH, Callahan LF. Prediction of long-term mortality in patients with rheumatoid arthritis according to simple questionnaire and joint count measures. Ann Intern Med 1994; 120: 26-34.

53. Callahan LF, Cordray DS, Wells G, Pincus T. Formal education and five-year mortality in rheumatoid arthritis: Mediation by helplessness scale scores. Arthritis Care Res 1996; 9: 463-72.

54. Callahan LF, Pincus T, Huston JW, III, Brooks RH, Nance EP, Jr., Kaye JJ. Measures of activity and damage in rheumatoid arthritis: Depiction of changes and prediction of mortality over five years. Arthritis Care Res 1997; 10: 381-94.

55. Söderlin MK, Nieminen $P$, Hakala M. Functional status predicts mortality in a community based rheumatoid arthritis population. J Rheumatol 1998; 25: 1895-9.

56. Sokka T, Hakkinen A, Krishnan E, Hannonen P. Similar prediction of mortality by the health assessment questionnaire in patients with rheumatoid arthritis and the general population. Ann Rheum Dis 2004; 63: 494-7.

57. Sokka T, Hakkinen A. Poor physical fitness and performance as predictors of mortality in normal populations and patients with rheumatic and other diseases. Clin Exp Rheumatol 2008; 26(5 Suppl 5): 14-20.

58. Stucki G, Liang MH, Stucki S, Brühlmann P, Michel BA. A selfadministered rheumatoid arthritis disease activity index (RADAI) for epidemiologic research. Arthritis Rheum 1995; 38: 795-8.

59. Sokka T, Kautiainen $H$, Toloza S, Makinen H, Verstappen SMM, Hetland ML et al. QUEST-RA: quantitative clinical assessment of patients with rheumatoid arthritis seen in standard rheumatology care in 15 countries. Ann Rheum Dis 2007; 66: 1491-6.

60. Ware JE, Jr., Sherbourne CD. The MOS 36-item short-form health survey (SF-36): I. Conceptual framework and item selection. Med Care 1992; 30: 473-81.

61. Felson DT, Anderson JJ, Boers M, Bombardier C, Furst D, Goldsmith $\mathrm{C}$ et al. American College of Rheumatology preliminary definition of improvement in rheumatoid arthritis. Arthritis Rheum 1995; 38: 727-35.

62. van der Heijde DMFM, van't Hof MA, van Riel PLCM, Theunisse LM, Lubberts EW, van Leeuwen MA et al. Judging disease activity in clinical practice in rheumatoid arthritis: first step in the development of a disease activity score. Ann Rheum Dis 1990; 49: 916-20.

63. van der Heijde DMFM, van't Hof M, van Riel PLCM, van de Putte LBA. Development of a disease activity score based on judgment in clinical practice by rheumatologists. J Rheumatol 1993; 20: 579-81.

64. Prevoo MLL, van't Hof MA, Kuper HH, van Leeuwen MA, van de Putte LBA, van Riel PLCM. Modified disease activity scores that include twenty-eight-joint counts: Development and validation in a prospective longitudinal study of patients with rheumatoid arthritis. Arthritis Rheum 1995; 38: 44-8.

65. Smolen JS, Breedveld FC, Schiff MH, Kalden JR, Emery P, Eberl $G$ et al. A simplified disease activity index for rheumatoid arthritis for use in clinical practice. Rheumatology (Oxford) 2003; 42: 244-57.

66. Aletaha D, Nell VPK, Stamm T, Uffmann M, Pflugbeil S, Machold KP et al. Acute phase reactants add little to composite disease activity indices for rheumatoid arthritis: validation of a clinical activity score. Arthritis Res Ther 2005; 7: R796-R806.

67. Makinen $H$, Kautiainen $H$, Hannonen $P$, Sokka $T$. A new disease activity index for rheumatoid arthritis: Mean Overall Index for Rheumatoid Arthritis (MOI-RA). J Rheumatol 2008; 35: 1522-7.

68. Kristensen LE, Saxne T, Geborek P. The LUNDEX, a new index of drug efficacy in clinical practice: results of a five-year observational study of treatment with infliximab and etanercept among rheumatoid arthritis patients in southern Sweden. Arthritis Rheum 2006; 54: 600-6.

69. Pincus T, Bergman MJ, Yazici $Y$, Hines $P$, Raghupathi $K$, Maclean R. An index of only patient-reported outcome measures, routine assessment of patient index data 3 (RAPID3), in two abatacept clinical trials: similar results to disease activity score (DAS28) and other RAPID indices that include physician-reported measures. Rheumatology (Oxford) 2008; 47: 345-9.

70. Pincus T, Swearingen CJ, Bergman M, Yazici Y. RAPID3 (routine assessment of patient index data 3), a rheumatoid arthritis index without formal joint counts for routine care: Proposed severity categories compared to DAS and CDAI categories. J Rheumatol 2008; 35: 2136-47.

71. Pincus T, Strand V, Koch G, Amara I, Crawford B, Wolfe F et al. An index of the three core data set patient questionnaire measures distinguishes efficacy of active treatment from placebo as effectively as the American College of Rheumatology $20 \%$ response criteria (ACR20) or the disease activity score (DAS) in a rheumatoid arthritis clinical trial. Arthritis Rheum 2003; 48: 625-30.

72. Pincus T, Amara I, Koch GG. Continuous indices of Core Data Set measures in rheumatoid arthritis clinical trials: lower 
responses to placebo than seen with categorical responses with the American College of Rheumatology $20 \%$ criteria. Arthritis Rheum 2005; 52: 1031-6.

73. Pincus T, Chung C, Segurado OG, Amara I, Koch GG. An index of patient self-reported outcomes (PRO Index) discriminates effectively between active and control treatment in 4 clinical trials of adalimumab in rheumatoid arthritis. J Rheumatol 2006; 33: 2146-52.

74. Pincus T, Sokka T, Kavanaugh A. Relative versus absolute goals of therapies for RA: ACR 20 or ACR 50 responses versus target values for "near remission" of DAS or single measures. Clin Exp Rheumatol 2004; 22(Suppl 35): S50-S56.

75. Puolakka K, Kautiainen H, Möttönen T, Hannonen P, Korpela M, Hakala M et al. Early suppression of disease activity is essential for maintenance of work capacity in patients with recent-onset rheumatoid arthritis: five-year experience from the FIN-RACo trial. Arthritis Rheum 2005; 52: 36-41.

76. Sharp JT, Lidsky MD, Collins LC, Moreland J. Methods of scoring the progression of radiologic changes in rheumatoid arthritis: correlation of radiologic, clinical and laboratory abnormalities. Arthritis Rheum 1971; 14: 706-20.

77. Sharp JT, Lidsky MD, Duffy J. Clinical responses during gold therapy for rheumatoid arthritis: changes in synovitis, radiologically detectable erosive lesions, serum proteins, and serologic abnormalities. Arthritis Rheum 1982; 25: 540-9.

78. Sharp JT. Radiographic evaluation of the course of articular disease. Clin Rheum Dis 1983; 9: 541-57.

79. Larsen A. A Radiological Method for Grading the Severity of Rheumatoid Arthritis. Espoo: Meder-Offset; 1974.

80. Larsen A, Dale K, Eek M. Radiographic evaluation of rheumatoid arthritis and related conditions by standard reference films. Acta Radiol [Diagn] (Stockh) 1977; 18: 481-91.

81. van der Heijde D. How to read radiographs according to the Sharp/van der Heijde method. J Rheumatol 1999; 26: 743-5.

82. Landewe $R$, van der Heijde $D$. Radiographic progression in rheumatoid arthritis. Clin Exp Rheumatol 2005; 23: S63-S68.

83. van der Heijde DMFM, van Leeuwen MA, van Riel PLCM, Koster AM, van't Hof MA, van Rijswijk MH et al. Biannual radiographic assessments of hands and feet in a three-year prospective followup of patients with early rheumatoid arthritis. Arthritis Rheum 1992; 35: 26-34.

84. Larsen A. How to apply Larsen score in evaluating radiographs of rheumatoid arthritis in longterm studies? J Rheumatol 1995; 22: 1974-5.

85. Kaarela $\mathrm{K}$, Kautiainen $\mathrm{H}$. Continuous progression of radiological destruction in seropositive rheumatoid arthritis. J Rheumatol 1997; 24: 1285-7.

86. Rau R, Herborn G. A modified version of Larsen's scoring method to assess radiologic changes in rheumatoid arthritis. J Rheumatol 1995; 22: 1976-82.

87. Rau R, Wassenberg S, Herborn G, Perschel WT, Freitag G. Identification of radiologic healing phenomena in patients with rheumatoid arthritis. J Rheumatol 2001; 28: 2608-15.

88. Pincus T, Larsen A, Brooks RH, Kaye J, Nance EP, Callahan LF. Comparison of 3 quantitative measures of hand radiographs in patients with rheumatoid arthritis: Steinbrocker Stage, Kaye Modified Sharp Score, and Larsen Score. J Rheumatol 1997; 24: 2106-12.

89. Pincus T, Sokka T. A three-page Standard Protocol to Evaluate Rheumatoid Arthritis (SPERA) for efficient capture of essential data from patients and health professionals in standard clinical care and clinical research. Best Pract Res Clin Rheumatol 2007; 21: 677-85.

90. Fuchs HA, Kaye JJ, Callahan LF, Nance EP, Pincus T. Evidence of significant radiographic damage in rheumatoid arthritis within the first 2 years of disease. J Rheumatol 1989; 16: 585-91.
91. Pincus T, Callahan LF, Brooks RH, Fuchs HA, Olsen NJ, Kaye JJ. Self-report questionnaire scores in rheumatoid arthritis compared with traditional physical, radiographic, and laboratory measures. Ann Intern Med 1989; 110: 259-66.

92. Sokka T, Toloza S, Cutolo $M$, Kautiainen $H$, Makinen $H_{\text {, }}$ Gogus $F$ et al. Women, men, and rheumatoid arthritis: analyses of disease activity, disease characteristics, and treatments in the QUEST-RA Study. Arthritis Res Ther 2009; 11: R7.

93. Sokka T, Kautiainen H, Pincus T, Toloza S, da Rocha Castelar Pinheiro G, Lazovskis J et al. Disparities in rheumatoid arthritis disease activity according to gross domestic product in 25 countries in the QUEST-RA database. Ann Rheum Dis 2009; 68: 1666-72.

94. Khan NA, Yazici Y, Calvo-Alen J, Dadoniene J, Gossec L, Hansen TM et al. Reevaluation of the Role of Duration of Morning Stiffness in the Assessment of Rheumatoid Arthritis Activity. J Rheumatol 2009; 36: 2435-42.

95. Naranjo A, Sokka T, Descalzo M, Calvo-Alén J, HorslevPetersen K, Luukkainen RK et al. Cardiovascular disease in patients with rheumatoid arthritis: results from the QUESTRA study. Arthritis Res Ther 2008; 10: R30-Epub ahead of print.

96. Sokka T, Pincus T. Quantitative joint assessment in rheumatoid arthritis. Clin Exp Rheumatol 2005; 23: S58-S62.

97. Wolfe F, Lassere $M$, van der Heijde D, Stucki G, SuarezAlmazor M, Pincus T et al. Preliminary core set of domains and reporting requirements for longitudinal observational studies in rheumatology. Omeract IV: Outcome measures in rheumatology. Cancun, Mexico, April 16-20, 1998. J Rheumatol 1999; 26: 484-9.

98. Sokka $T$, Hetland $M L$, Makinen $H$, Kautiainen $H$, HorslevPetersen K, Luukkainen RK et al. Remission and rheumatoid arthritis: Data on patients receiving usual care in twentyfour countries. Arthritis Rheum 2008; 58: 2642-51.

99. Sokka T, Hakkinen A, Kautiainen $H$, Maillefert JF, Toloza S, Mork Hansen $T$ et al. Physical inactivity in patients with rheumatoid arthritis: data from twenty-one countries in a cross-sectional, international study. Arthritis Rheum 2008; 59: 42-50.

100. Verstappen SM, Jacobs JW, Huisman AM, van Rijthoven AW, Sokka T, Bijlsma JW. Functional Health Assessment Questionnaire (HAQ) and Psychological HAQ Are Associated with and Predicted by Different Factors in Rheumatoid Arthritis. J Rheumatol 2007; 34: 1837-40.

101. Gogus F, Yazici Y, Yazici H. Inclusion criteria as widely used for rheumatoid arthritis clinical trials: patient eligibility in a Turkish cohort. Clin Exp Rheumatol 2005; 23: 681-4.

102. Waaler $H$, Starky $C$. What is the best indicator of health care? World Health Forum 1984; 5: 276-9.

103. Tresserras R, Canela J, Alvarez J, Sentis J, Salleras L. Infant mortality, per capita income, and adult illiteracy: an ecological approach. Am J Public Health 1992; 82: 435-8.

104. Janssen F, Kunst AE, Mackenbach JP. Association between gross domestic product throughout the life course and old-age mortality across birth cohorts: parallel analyses of seven European countries, 1950-1999. Soc Sci Med 2006; 63: 239-54.

105. Micheli A, Coebergh JW, Mugno E, Massimiliani E, Sant M, Oberaigner $\mathrm{W}$ et al. European health systems and cancer care. Ann Oncol 2003; 14(suppl 5): v41-v60.

106. Sokka T. Long-term outcomes of rheumatoid arthritis. Curr Opin Rheumatol 2009; 21: 284-90.

107. Makinen $\mathrm{H}$, Hannonen $\mathrm{P}$, Sokka T. Definitions of remission for rheumatoid arthritis and review of selected clinical cohorts and randomized clinical trials for the rate of remission. Clin Exp Rheumatol 2006; 24 (S43): S22-S28. 
108. Forslind K, Hafstrom I, AhImen M, Svensson B. Sex: a major predictor of remission in early rheumatoid arthritis? Ann Rheum Dis 2007; 66: 46-52.

109. Mancarella L, Bobbio-Pallavicini F, Ceccarelli F, Falappone PC, Ferrante A, Malesci D et al. Good clinical response, remission, and predictors of remission in rheumatoid arthritis patients treated with tumor necrosis factor-alpha blockers: the GISEA study. J Rheumatol 2007; 34: 1670-3.

110. Hyrich KL, Watson KD, Silman AJ, Symmons DP, British Society for Rheumatology Biologics Register. Predictors of response to anti-TNF-\{alpha\} therapy among patients with rheumatoid arthritis: results from the British Society for Rheumatology Biologics Register. Rheumatology (Oxford) 2006; 45: 1558-65.

111. Yamanaka H, Tanaka $Y$, Sekiguchi N, Inoue $E$, Saito $K$, Kameda $\mathrm{H}$ et al. Retrospective clinical study on the notable efficacy and related factors of infliximab therapy in a rheumatoid arthritis management group in Japan (RECONFIRM). Mod Rheumatol 2007; 17: 28-32.

112. Kvien TK, Uhlig T, Odegard S, Heiberg MS. Epidemiological aspects of rheumatoid arthritis: the sex ratio. Ann N Y Acad Sci 2006; 1069: 212-22.

113. Miller $A$, Green $M$, Robinson D. Short rule for calculating normal erythrocyte sedimentation rate. Br Med J 1983; 286: 266.

114. Sokka T, Envalds M, Pincus T. Treatment of rheumatoid arthritis: a global perspective on the use of antirheumatic drugs. Mod Rheumatol 2008; 18: 228-39.

115. Blair SN, Kohl HW3, Paffenbarger RS, Jr., Clark DG, Cooper $\mathrm{KH}$, Gibbons LW. Physical fitness and all-cause mortality. A prospective study of healthy men and women. JAMA 1989; 262: 2395-401.

116. Work group recommendations: 2002 Exercise and Physical Activity Conference, St. Louis, Missouri. Session V: evidence of benefit of exercise and physical activity in arthritis. Arthritis Rheum 2003; 49: 453-4.

117. ACR Subcommittee on Rheumatoid Arthritis Guidelines. Guidelines of the management of rheumatoid arthritis: 2002 update. Arthritis Rheum 2002; 46: 328-46.

118. Häkkinen A, Sokka T, Kotaniemi A, Hannonen P. A randomized two-year study of the effects of dynamic strength training on muscle strength, disease activity, functional capacity, and bone mineral density in early rheumatoid arthritis. Arthritis Rheum 2001; 44: 515-22.

119. Stenstrom $\mathrm{CH}$. Therapeutic exercise in rheumatoid arthritis. Arthritis Care Res 1994; 7: 190-7.

120. Yelin E, Meenan R, Nevitt M, Epstein W. Work disability in rheumatoid arthritis: effects of disease, social, and work factors. Ann Intern Med 1980; 93: 551-6.

121. Mäkisara GL, Mäkisara P. Prognosis of functional capacity and work capacity in rheumatoid arthritis. Clin Rheumatol 1982; 1: 117-25.

122. Sokka T, Krishnan E, Häkkinen A, Hannonen P. Functional disability in rheumatoid arthritis patients compared with a community population in Finland. Arthritis Rheum 2003; 48: 59-63.
123. Sokka T. Work disability in early rheumatoid arthritis. Clin Exp Rheumatol 2003; 21: S71-4.

124. Verstappen SM, Jacobs JW, Hyrich KL. Effect of anti-tumor necrosis factor on work disability. J Rheumatol 2007; 34: 2126-8.

125. Yelin E, Trupin L, Katz P, Lubeck D, Rush S, Wanke L. Association between etanercept use and employment outcomes among patients with rheumatoid arthritis. Arthritis Rheum 2003; 48: 3046-54.

126. Smolen JS, Han C, van der Heijde D, Emery P, Bathon JM, Keystone $E$ et al. Infliximab treatment maintains employability in patients with early rheumatoid arthritis. Arthritis Rheum 2006; 54: 716-22.

127. Kimel M, Cifaldi M, Chen N, Revicki D. Adalimumab plus methotrexate improved SF-36 scores and reduced the effect of rheumatoid arthritis (RA) on work activity for patients with early RA. J Rheumatol 2008; 35: 206-15.

128. Anis A, Zhang W, Emery P, Sun H, Singh A, Freundlich B et al. The effect of etanercept on work productivity in patients with early active rheumatoid arthritis: results from the COMET study. Rheumatology (Oxford) 2009; 48: 1283-9.

129. Kavanaugh A, Smolen JS, Emery P, Purcaru O, Keystone E, Richard $L$ et al. Effect of certolizumab pegol with methotrexate on home and work place productivity and social activities in patients with active rheumatoid arthritis. Arthritis Rheum 2009; 61: 1592-600.

130. Wolfe F, Allaire S, Michaud K. The prevalence and incidence of work disability in rheumatoid arthritis, and the effect of anti-tumor necrosis factor on work disability. J Rheumatol 2007; 34: 2211-7.

131. Allaire S, Wolfe F, Niu J, Zhang Y, Zhang B, LaValley M. Evaluation of the effect of anti-tumor necrosis factor agent use on rheumatoid arthritis work disability: the jury is still out. Arthritis Rheum 2008; 59: 1082-9.

132. Laas K, Peltomaa R, Kautiainen H, Puolakka K, LeirisaloRepo M. Pharmacoeconomic study of patients with chronic inflammatory joint disease before and during infliximab treatment. Ann Rheum Dis 2006; 65: 924-8.

133. Augustsson J, Neovius M, Cullinane-Carli C, Eksborg S, van Vollenhoven RF. Rheumatoid arthritis (RA) patients treated with TNF-antagonists increase their participation in the work-force potential for significant long-term indirect cost gains. Data from a population-based registry. Ann Rheum Dis 2010; 69: 126-31.

134. Eberhardt K. Very early intervention is crucial to improve work outcome in patients with rheumatoid arthritis. J Rheumatol 2009; 36: 1104-6.

135. Chung CP, Sokka T, Arbogast P, Pincus T. Work disability in early rheumatoid arthritis: higher rates but better clinical status in Finland compared with the US. Ann Rheum Dis 2006; 65: 1653-7.

136. Sokka T, Kautiainen H, Pincus T, Verstappen SM, Aggarwal A, Alten $\mathrm{R}$, et al. Work disability remains a major problem in rheumatoid arthritis in the 2000s: data from 32 countries in the QUEST-RA study. Arthritis Res Ther. 2010; 12: R42. 